امكانسنجى استفاده از تفاله ريشه شيرينبيان (Glycyrrhiza glabra L.) بهعنوان بستر رشد و تأثير آن بر ويزگى هاى رشد و جذب عناصر غذايى در كشت بدون خاك توتفرنحى

\author{
محمدرضا صفىزاده'”، حميدرضا بوستانى 'و عباس ميرسليمانى'
}

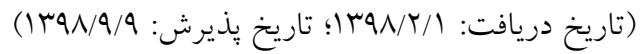

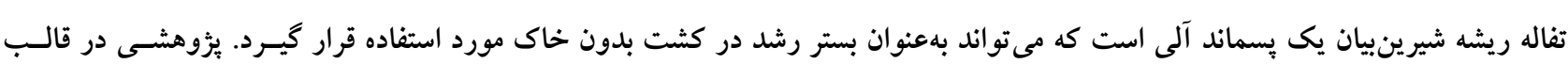

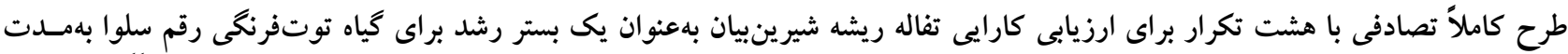

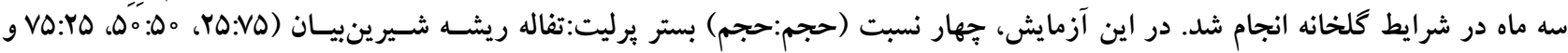

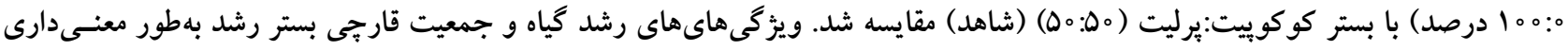

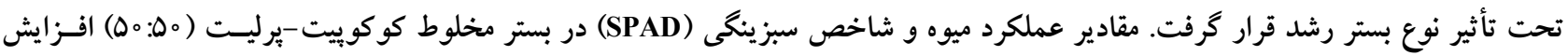

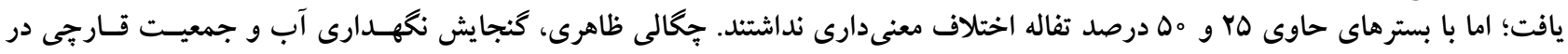

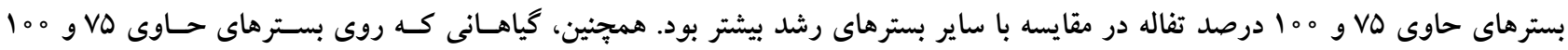

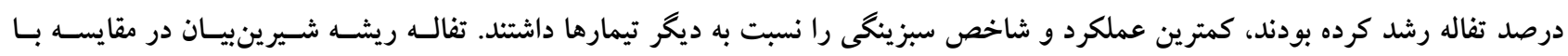

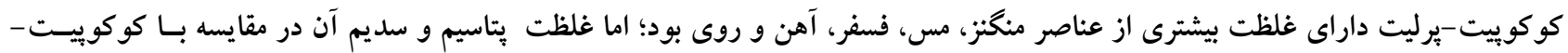

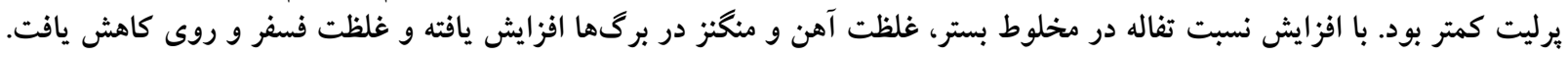

وازمهاى كليدى: جمعيت قارجى، عملكرد، كوكوييت، شاخص سبزينكى (SPAD)

فر اوردههاى ميوهاى، اغلب ممكن اسـت بـهـ مقــادير بيشترى از

مقدمه

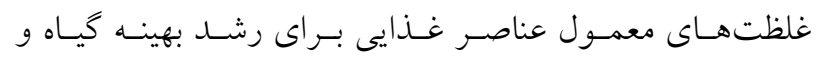
در روشهاى متداول كاشت، تنشهاى زنسـده و غيرزنــه باعـث

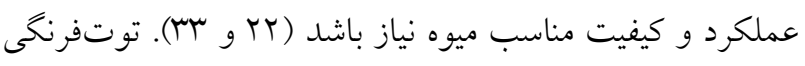

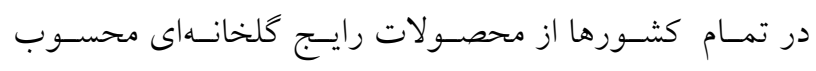

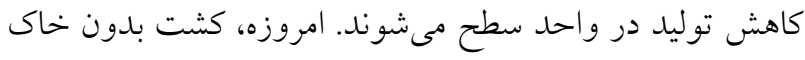

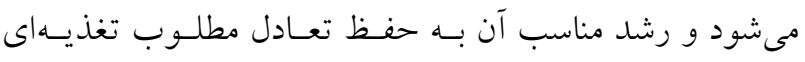

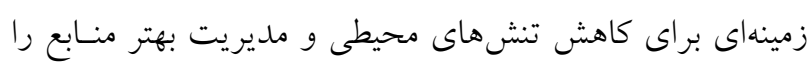

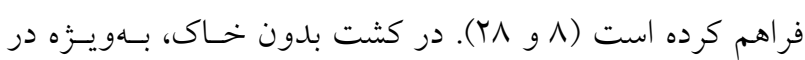

ا. گرووه توليدات گياهى، دانشكده كشاورزى و منابع طبيعى داراب، دانشخاه شيراز

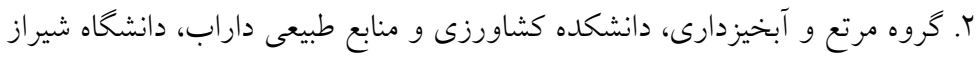

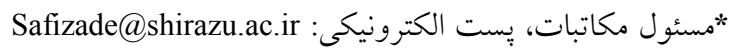


بر رشد كياه گوجهفرنخـى و جمعيـت اسـيور قـارج فوزاريـوم،

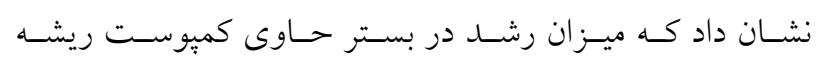

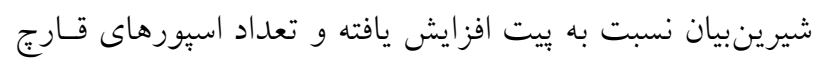

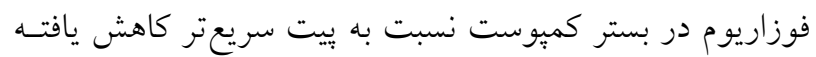

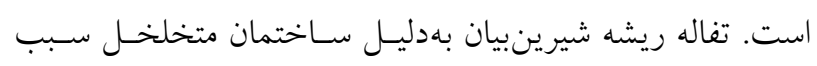

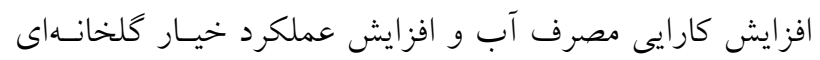

شده است (Yq).

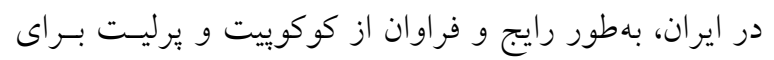
تهيه بستر رشد بلدون خاك استفاده مىشـود. سـالانه ميليـونهـا

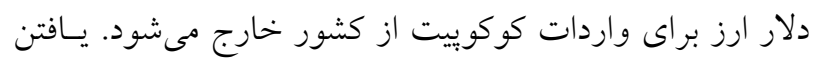

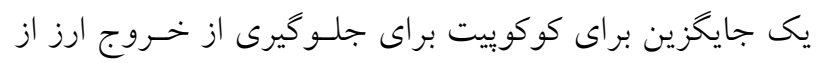

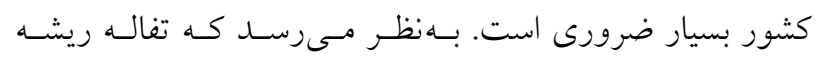

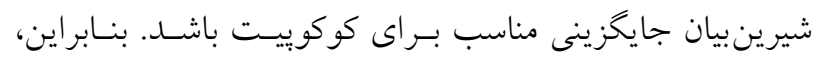

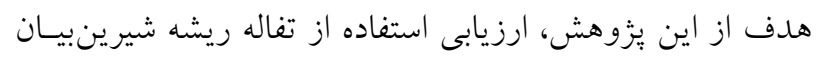

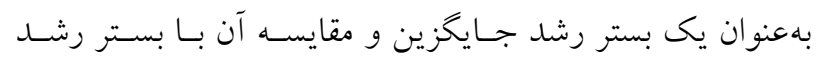

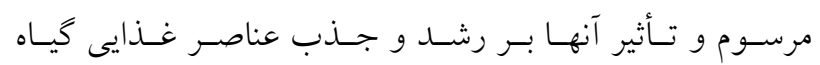
توتفرنكى تحت شرايط كشت بدون خاك بود.

\section{مواد و روشها}

\section{سيستم كاشت و تركيب محلول غذايى}

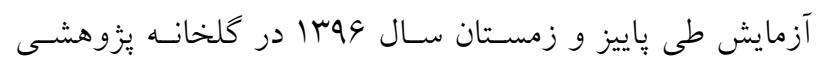

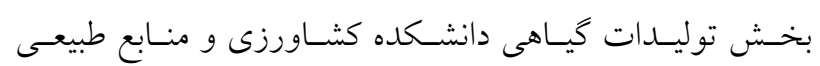

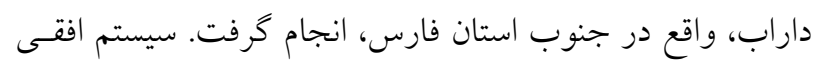

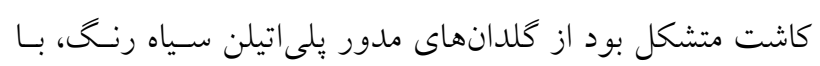

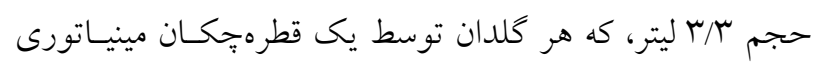

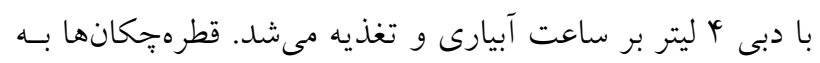

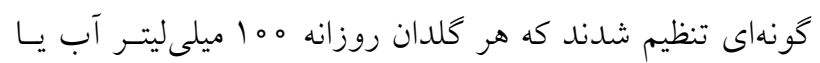

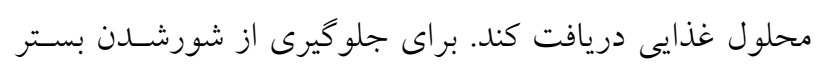

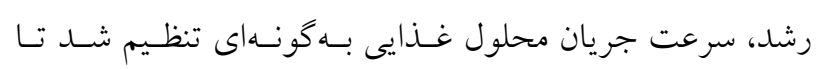

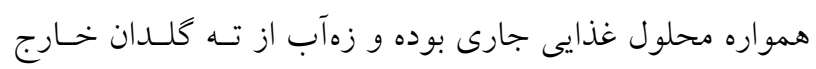

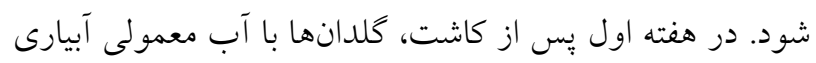

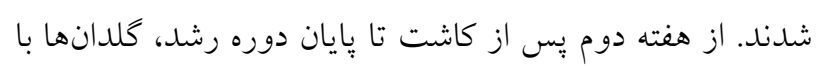

در مراحل رشد رويشى و زايشى بستخى دارد (سا). مو ادى كه

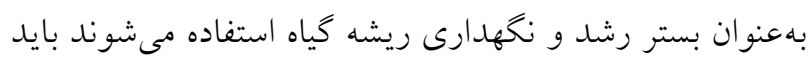

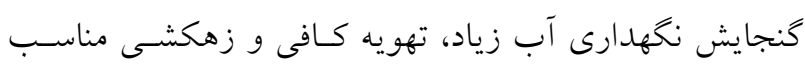

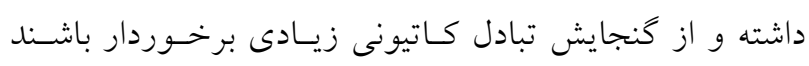

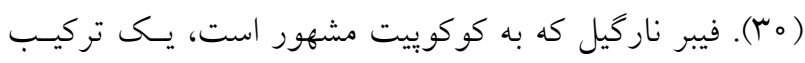

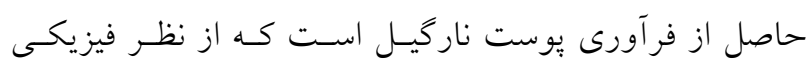

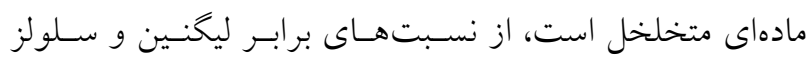

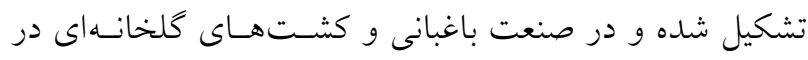

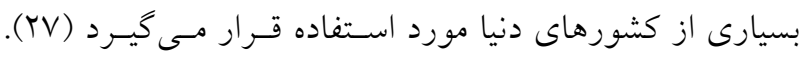

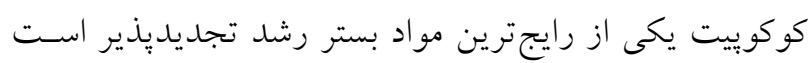

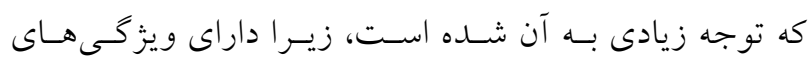

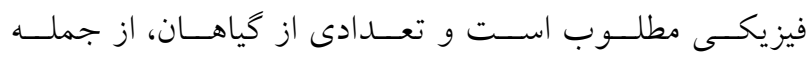
توتفرنكى، بهطور موفقيتآميزى در آن رشد كـردهانـد (YY).

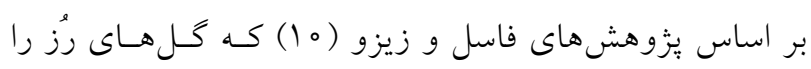

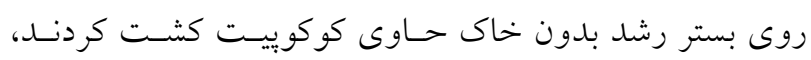

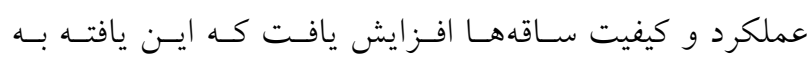

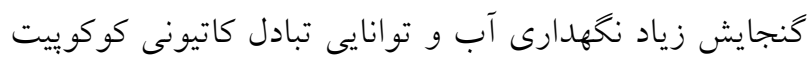

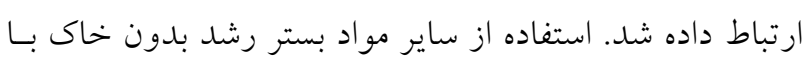

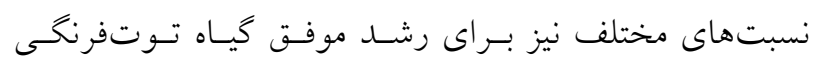

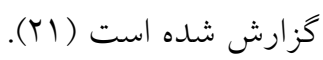

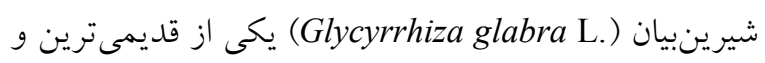

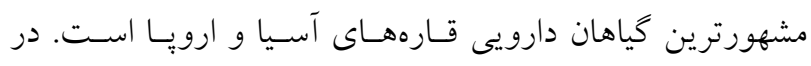

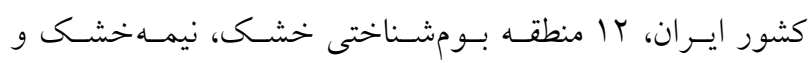

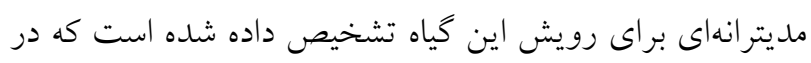

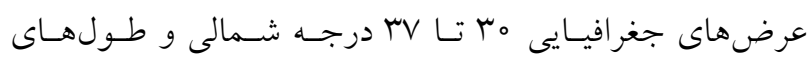

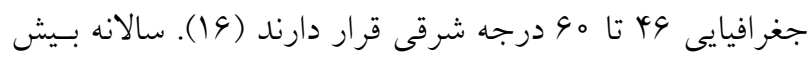

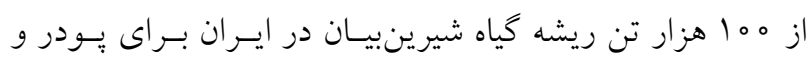

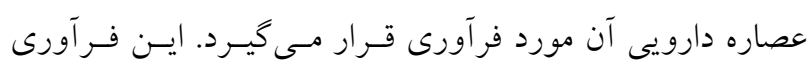

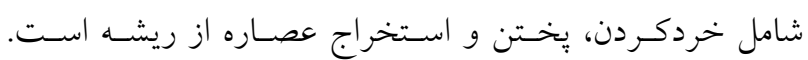

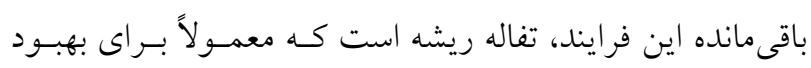

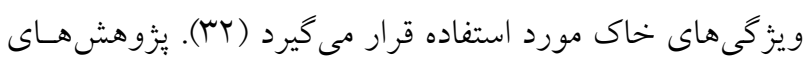
مدينا و همكاران (Y) در مورد اثر كميوست ريشه شسيرين بيـان 


\begin{tabular}{|c|c|c|c|}
\hline \multicolumn{2}{|c|}{ عناصر كممصرف (mg/L) } & \multicolumn{2}{|c|}{ عناصر يرمصرف (mg/L) } \\
\hline 1 & آهن & Too & نيتروزن \\
\hline$\circ / 0$ & مس & Yoo & فسفر $\left(\mathrm{P}_{\mathrm{Y}} \mathrm{O}_{\mathrm{C}}\right.$ \\
\hline$\circ / 0$ & روى & Yoo & يتاسيم (K,O) \\
\hline$\circ / 0$ & منكنز & & \\
\hline $0 / T$ & بور & & \\
\hline
\end{tabular}

جدول r. برخى ويزگى هاى شيميايى و غلظت عناصر غذايى (ميلى گرم بر كيلو گرم) بسترهاى رشد مورد استفاده در كشت بدون خاك توتفرنكى رقم سلوا

\begin{tabular}{|c|c|c|c|c|c|c|c|c|c|}
\hline $\mathrm{Cu}$ & $\mathrm{Zn}$ & $\mathrm{Mn}$ & $\mathrm{Fe}$ & $\mathrm{Na}$ & $\mathrm{K}$ & $\mathrm{P}$ & $\begin{array}{c}\mathrm{EC} \\
(\mathrm{dS} / \mathrm{m})\end{array}$ & $\mathrm{pH}$ & تركيب بستر رشد \\
\hline$r / r$ & $1 / V 0$ & Q० & pat & 1000 & Yl०0 & roo & $\circ / \mu \circ r$ & $V / 01$ & •ه\%٪ كوكوييت + • هـ\% برليت \\
\hline- & - & - & - & - & - & - & $\circ / \mu$ & $\mathrm{V} / \mathrm{QS}$ & 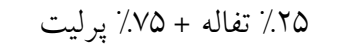 \\
\hline- & - & - & - & - & - & - & $\circ / \mu^{4}$ & $V / T Q$ & •هـ\% تفاله + •هـ/ برليت \\
\hline- & - & - & - & - & - & - & $0 / T V$ & V/or & 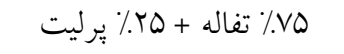 \\
\hline$Q / Y$ & TV & 111 & 190r & $0 \circ 0$ & 1000 & 900 & $0 / \mu$ & $V / 4 \Lambda$ & هـ 1\% تفاله \\
\hline
\end{tabular}

كلدان فشرده شدند. نشاهاى توتفرنخـى (رقـم سـلوا) كـه نيـاز

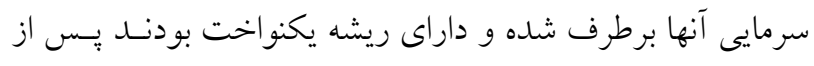

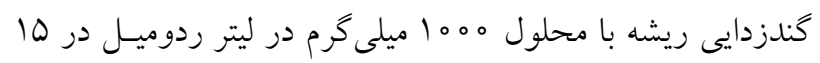

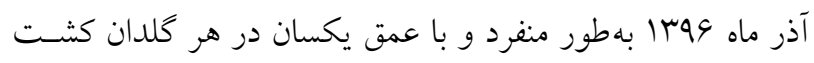
شدند. برخى از ويزگى هاى شيميايى بسترهاى رشد مورد استفاده در جدول (r) آورده شده است.

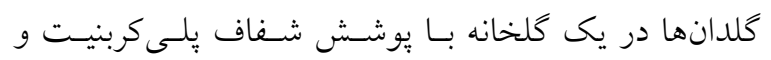

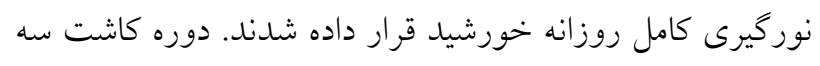

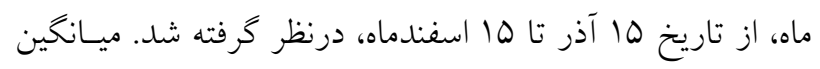

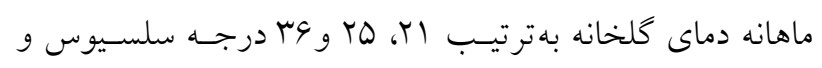
رطوبت نسبى آن هV/ بود.

اندازهيرى pH و pC

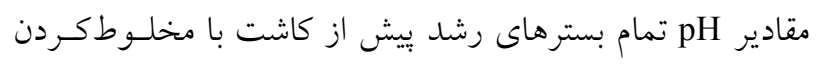

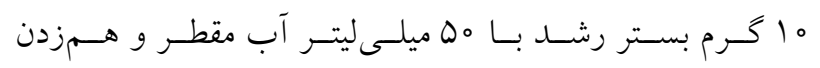

محلول غذايى (AGRIMEL, Netherlands) بهميـزان 0 (1) ميلسيتيـر در روز (EC=l// dS/m ، pH= تغذيه شدند (جدول 1). تيمارها و جخگونغى كاشت تفاله ريشه شيرينبيان جمع آورىشده از اقليم نيمه خشكى دشـمن

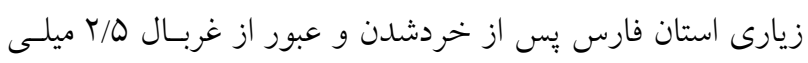

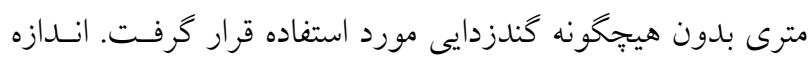

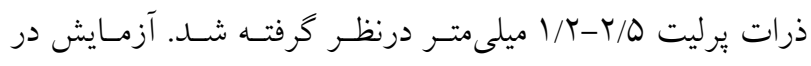

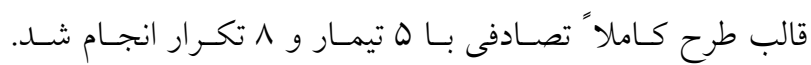

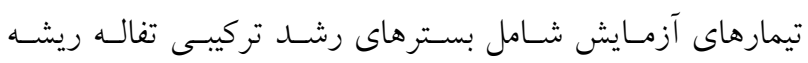

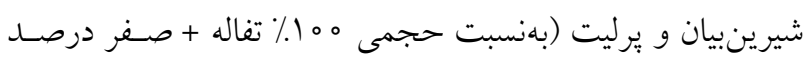

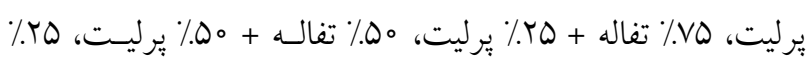

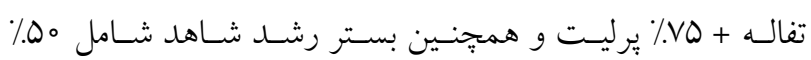

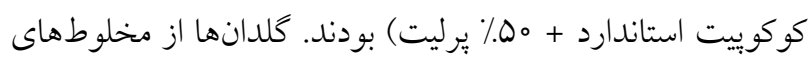

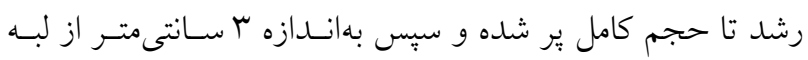


DW وزن خشك نمونه و VW حجم سيلندر است (11).

اندازه گيرى شاخص هاى رشد در بايان دوره رشلد، بوتهها از كلدان و بستر رشد بـهدقـت خـارج شدند و شاخساره و ريشه از محل طوقه از هم جـــا شــده و وزن تازه آنها جداكانه تعيين شد. براى تعيين وزن خشك، بوتهها براى مدت ^^ا ساعت در آون با دماى •م درجه سلسيوس قرار كرفتند و سبِ وزن خشك با استفاده از ترازوى ديجيتال تعيين شـــ. بـا توجه به غيريكنواختبودن گل ادهى، گل هاى تمامى بوتهها در مـاه

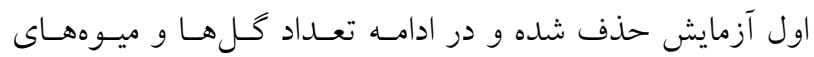
توليدشده در دو ماه يايـانى شـمارش شـده و وزن شــند. ميـزان سبزينگى برگها (9 بر گجهه توسعهيافته سـاده از هـر بوتسه) در دو

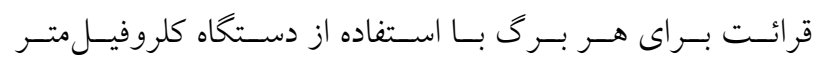
SPAD-502 (Konica Minolta, Singapore)

\section{تعيين غلظت عناصر غذايى}

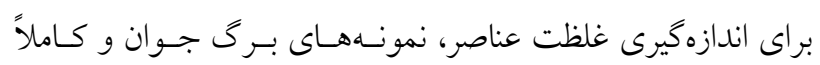

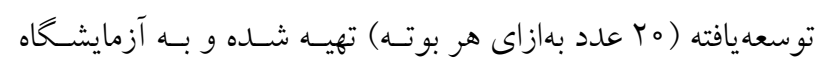

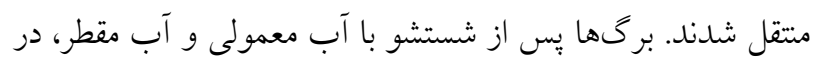

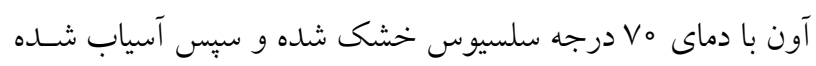

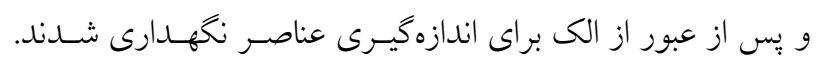

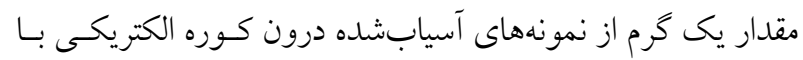
دماى •مه درجه سلسيوس بهمدت ه سـاعت بـه خاكستر تبـديل شدند. خاكسـتر حاصـل بـا اسـتفاده از اسـيد كلريـدريك ب مــولار عصاره گيرى شده و از كاغذ صافى عبور داده شد. براى اندازهيـرى

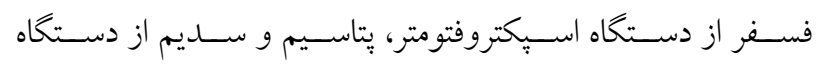
فلـيم فتـومتر (Corning 410, Sherwood Scientific, Ltd, UK) و براى انــازهزيـرى آهـن، مسس و روى از دسـتخاه جـــب اتمسى

(PG 990. PG Instruments Ltd. UK)

$$
\text { تعيين كيفيت ميكروبى بستر رشد }
$$

جمعيت باكترىهاى هوازى مزوفيليك، مخمر و قارجها توسـط بـ
و نخهدارى بهمدت ب M ساعت توسـط دسـخاه pH متـر تعيـين شد. براى تعيسين رسـانايى الكتريكىى (EC)، مب خــرم از بسـتر

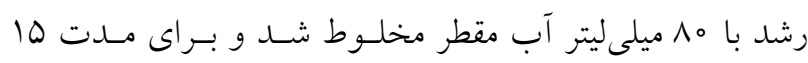
دقيقه تكان داده شد و بــهـــ مخلوطها يس از صاف كردن، توسط EC متـر خوانـده شـد. pH و بC بسترها يس از كاشـت در زمآب كلـدانهـا در هفتـه اول كشت بلدون محلول غذايى و در هفتـه آخـر كشـت بـا محلـول

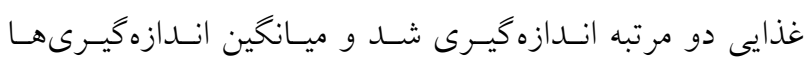

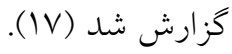

اندازهيرى جُخالى ظاهرى و حقيقـى، تخلخـل و گنجــايش نخهدارى آب

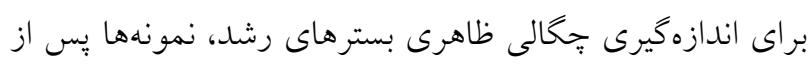

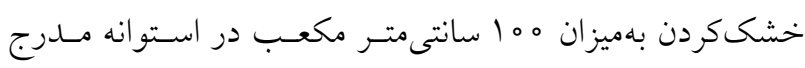
قرار داده شده و يس از وزنكردن، جّالى ظاهرى برحسب گرم بر سانتى متر مكعب محاسـبه شـــ. جخــالى حقيقـى نيـز توسـط

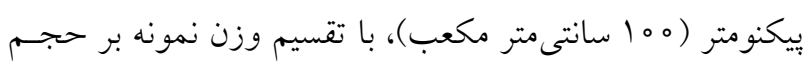
ذرات نمونه، ارزيابى شد، بهذونهاى كـه حجـم ذرات نمونسه از

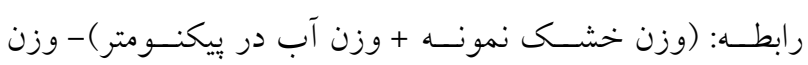
ييكنومتر و آب) تعيين شد. درصد تخلخل بر اساس رابطـه زيسر تعيين شد: $\mathrm{n}=\left(1-\frac{\rho_{\mathrm{b}}}{\rho_{\mathrm{s}}}\right) \times 1 \circ \circ$

كه n تخلخل، براى محاسبه كنجايش نخهارى آب، نمونههـاى بسـترهاى

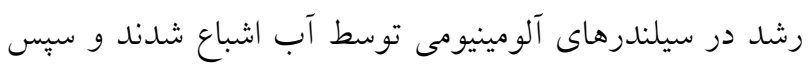

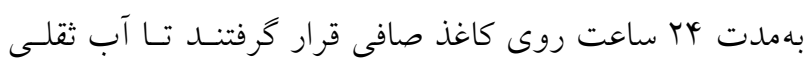

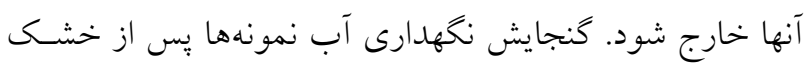

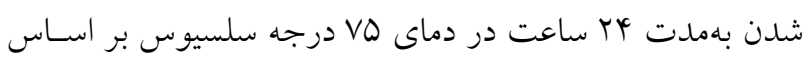
رابطه زير تعيين شد: $\mathrm{WHC}=\left(\frac{\mathrm{WW}-\mathrm{DW}}{\mathrm{V}}\right) \times 1 \circ$ 。 كه WHC گنجايش نخهــدارى آب، WW وزن مرطـوب نمونـه، 
جدول r. مقايسه ميانخين ويزّگىهاى شيميايى بسترهاى رشد در دو زمان متفاوت

\begin{tabular}{|c|c|c|c|c|}
\hline \multicolumn{2}{|c|}{ هفته آخر كشت (همراه با محلول غذايى) } & \multicolumn{2}{|c|}{ هفته اول كشت (بدون محلول غذايى) } & \multirow[b]{2}{*}{ 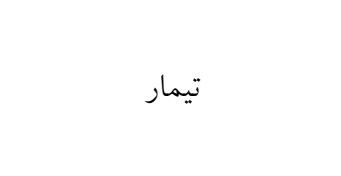 } \\
\hline $\mathrm{pH}$ & رساناى الكتريكى (EC) & $\mathrm{pH}$ & رسانايى الكتريكى (EC) & \\
\hline $\mathrm{V} / \mathrm{IT}^{\mathrm{wb}}$ & $T / \backslash \Lambda^{a}$ & $\Delta / \circ \Delta^{b}$ & $1 / 90^{\circ}$ & 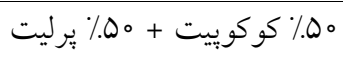 \\
\hline $\mathrm{V} / 99^{\mathrm{a}}$ & $1 / \Delta \mu^{\mathrm{b}}$ & $\Lambda / I V^{a}$ & $\circ / 9 \Delta^{\mathrm{b}}$ & 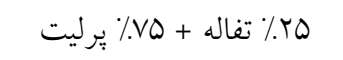 \\
\hline$V / 9)^{a}$ & $1 / \Delta r^{\mathrm{b}}$ & $\Lambda / \wedge \wedge^{\mathrm{a}}$ & $\circ / 9 Y^{b}$ & 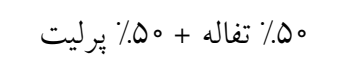 \\
\hline $\mathrm{V} / \Lambda^{\mathrm{a}}$ & $1 / 99 \mathrm{~b}$ & $\Lambda / 1 Q^{\mathrm{a}}$ & $\circ / V \Delta^{b}$ & 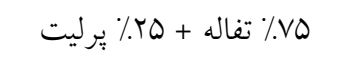 \\
\hline $\mathrm{V} / 99^{\circ}$ & $1 / \Delta \Delta^{b}$ & $\Lambda / \circ V^{a}$ & $\circ / \wedge \circ b$ & هـ 1\% تفاله \\
\hline
\end{tabular}

در هر ستون، ميانخينهاى با حداقل يك حرف مشترك، اختلاف معنىدارى در سطح هـ٪ بر اساس آزمون LSD ندارند.

يار امترها مستقيماً بر فراهمى عناصر غذايى تـأثير مسى خذارنـــ و بيانكر ماهيت ذاتى مـواد بسـتر رشــ نيـز هسـتند. تغييـرات در تركيب يك بستر بهطور مؤثر بر gH و EC بستر رشد تـأثير مسى

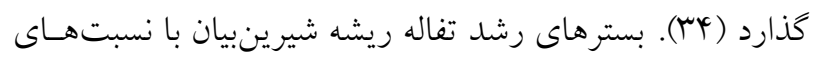
حجمى مختلف در ابتداى كشت و بلدون كاربرد محلول غـذايى

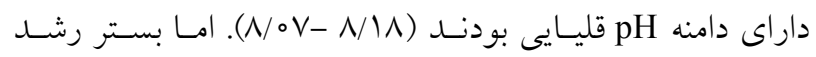
كوكوييت-يرليت در اين مرحله اسيدى بود (ه/ه) (جدول ما). بسترهاى رشد تفاله بِ از كاربرد محلول غـذايى از دامنـه

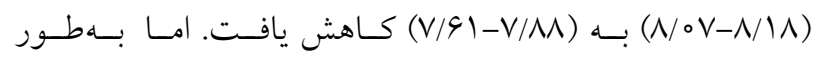
معنسى دارى بيشـترى نسـبت بـه كوكوييـت - بيرليـت (V/TY) داشتند. كاهش pH بسترهاى آلى يـك يديــه معمـولى اسـت و

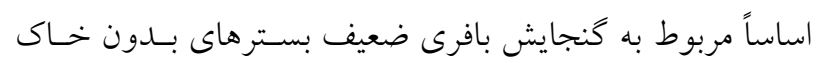
است كه در برابر اسيدىشدن محيط توسط ريشه يـا اسـتفاده از كودهاى اسيدى مقاومت نمى كنند (Y). هر جنـل كونههاى گيـاهى و ارقام مختلف داراى يك دامنه pH بهينه براى رشد هستند. اما بهطور كلى، pH بهينه بستر بدون خاك بـراى فراهمسى مطلـوب عناصر غذايى حدود 9 است ( آY). pH بسـترهـاى رشـــ تفالـه اختلاف معنى دارى بـا هـم نداشـتند. بـهنظـر مسىرسـد اجـزاى pH تشكيلدهنده اين دو نوع بستر رشد سبب اختلاف معنسىدار شده است. مقادير دامنه pH بسـترهـاى رشـــ تفالـه بـراى گيـاه توتفرنخى در سيستمهاى بدون خاك بهعنوان pH قابـل قبـول در نظر كرفته شده است (Y) (Y).
روش شمارش كل يترىديش (TO) با كمى تغييرات انـدازهذيـرى شد. براى شمارش باكترىهاى هوازى مزوفيليك از محيط كشـت ويزه اين روش و براى شمارش مخمر و قارجها از محيط كشـت

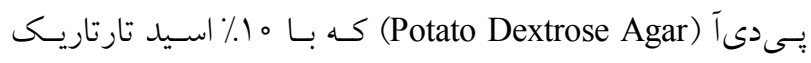
اسيدى شده بود استفاده شد. ده ميلى ليتر از زهآب هر كلدان با هالب

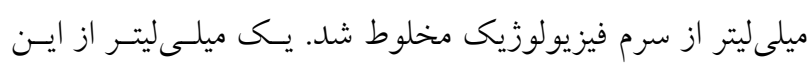

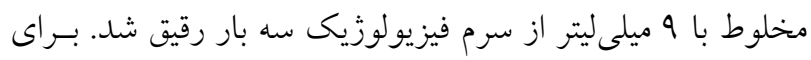

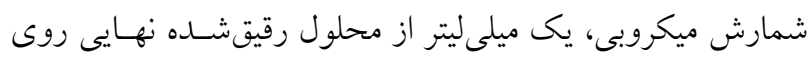

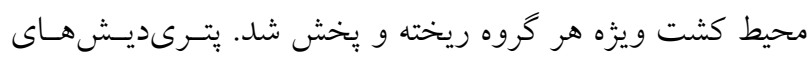

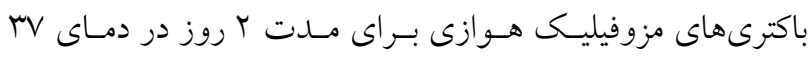
درجه سلسيوس و يترىديش هاى مخمر و قارجها بـراى مـــت م روز در دماى هr درجه سلسـيوس قـرار داده شــند. يـس از آن، كلنى ميكروبى يترىديشها شمارش شد. يردازش دادهها دادههاى حاصل از آزمايش با نرم|فزار 9.1 SAS v مورد تجزيـه. و تحليل قرار گرفتند و مقايسه ميانخينها توسط آزمون كمتـرين اختلاف معنى دار (LSD) در سطح احتمال ه. انجام گرفت.

نتايج و بحث تغييرات pH و ECH تحت تأثير نوع بستر رشد pH و مهم ترين ويزگى هاى هر بستر رشد هستند، زيرا ايسن 
جدول أ. برخى ويزّى هاى فيزيكى و شيميايى بسترهاى رشد مورد استفاده بيش از كشت توتفرنكى رقم سلوا

\begin{tabular}{|c|c|c|c|c|c|c|}
\hline $\begin{array}{c}\mathrm{EC} \\
(\mathrm{dS} / \mathrm{m})\end{array}$ & $\mathrm{pH}$ & نخهادارى آبش & تخلخل & $\begin{array}{c}\text { حالى حقيقح } \\
\left(\mathrm{g} / \mathrm{cm}^{r}\right)\end{array}$ & كالى ظاهر & نوع بستر رشد \\
\hline$\circ / \mu_{0}$ & $V / 01$ & $\Delta V / c$ & $\Lambda \varepsilon / 4$ & $1 / T Q$ &.$/ \mathrm{V}$ & مهـ\% كوكوبيت + مهـ\% برليت \\
\hline$\circ / \mu_{\circ}$ & $V / D Q$ & $x+/ 9$ & $V Q / \circ$ & $0 / 90$ &.$/ 10$ & 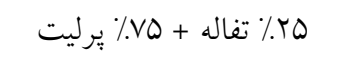 \\
\hline$\circ M Y$ & $V / T \Delta$ & $\Delta \circ / 4$ & $V 9 / 9$ &.$/ 90$ & $0 / 10$ & •هـ\% تفاله + •هـ٪ يرليت \\
\hline $0 / T V$ & V/Or & $\Delta \psi / 1$ & $\vee \vee / ० \circ$ & $1 / 00$ & $0 / Y 1$ & 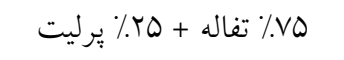 \\
\hline$\circ / \mu$ & $\Lambda / \circ \circ$ & $9 \circ / 4$ & $\Lambda \circ / \Lambda$ & $1 / \Gamma_{0}$ & $\circ / T Q$ & هـ 1\% تفاله \\
\hline
\end{tabular}

دانهالها و محصولات قابل قبـول شـناخته شـده اسـت (1)).

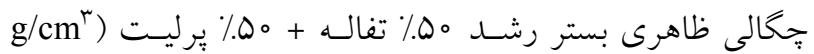
ها

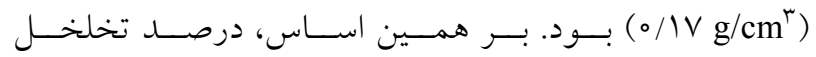

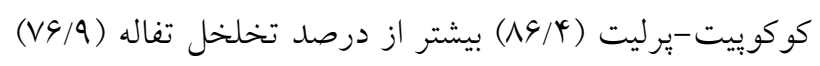
بود. بنابراين، تهويه در بستر رشـد كوكوبيـت -يرليـت بهتـر از ساير تركيبهاى بستر رشد است. درصد تخلخل معيارى براى تهويه محيط ريشه است. زمانى كه تهويه محسيط ريشـه كـافى باشد ريشه بهآسـانى در بسـتر نفـوذ كـرده و حجـم و فضـاى بيشترى از محيط را اشغال مى كند. درنتيجـه، تـأمين آب قابـل استفاده و جذب عناصر غذايى براى رشد كياه در ايسن محسيط بهتر صورت مى گيرد. گنجايش نخهـدارى آب در بسـتر رشـد

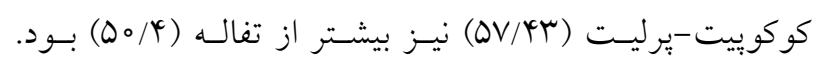

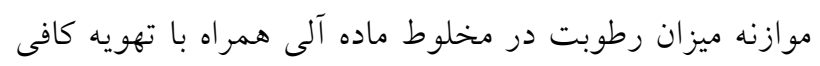
باعث استقرار خوب شرايط محيطى در اطــراف ناحيـه ريشـه

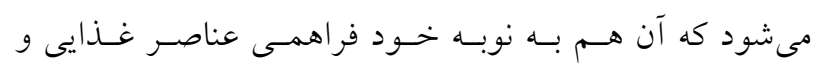

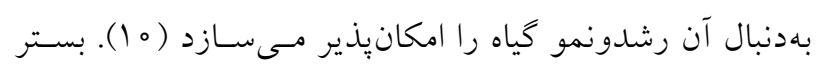

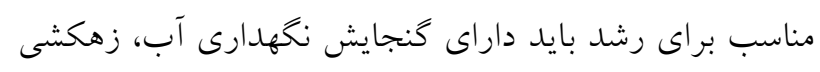
سريع و تهويه مناسب باشد. اين ويز كى ها مستقيماً تحت تأثير توزيع اندازه ذرات و جّالى ظاهرى بستر رشد قرار مسى گيـرد

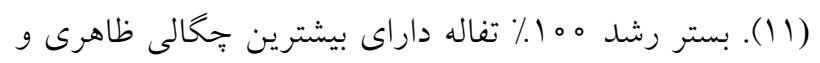
بيشترين كنجايش نخهارى آب بود. اين نتايج شبيه به آمرى و

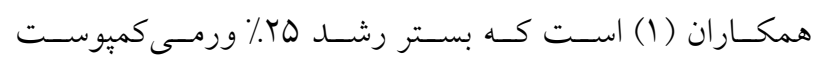

بستر كوكوبيت - برليت (1/9 dS/m در هفته اول كشـت، بدون محلول غذايى نسبت به بسترهاى تفالـه ريشـه شـيرينبيـان

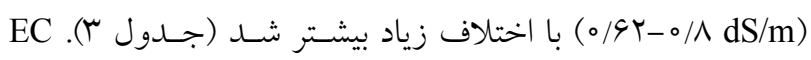
تمام بسترهاى رشد بِس از تغذيـهـ بــا محلـول غــذايى و در هفتـه.

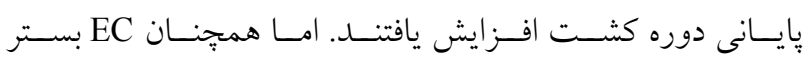
كوكوبيت-بِرليت بهطور معنى دارى بيشتر از EC بسـترهـاى رشـــ

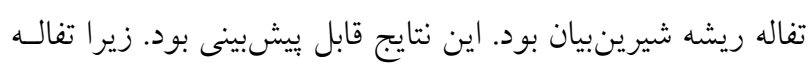

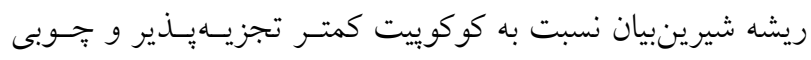

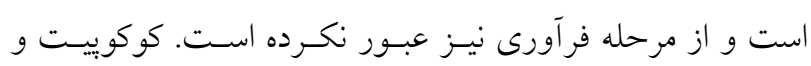
كمبوستها موادى با EC زياد هستند. زيرا كوكوبيـت در مراحـل تهيه، با آب دريا شستشو مىشود و كمبوست ها طى فراينـد، كـود دريافت مىدارند (YV) افزايش EC بسترهاى رشد يس از كـاربرد محلول غذايى و در اواخر هفته كشت به EC محلول غذايى ربـط داده مىشود. اما اختلاف معنى دار EC دو نــوع بسـتر رشـــ نشـان مىدهد كه EC نيز همانند pH تحت تـأثير اجـزاى تشـكيلدهنــده بسترهاى رشد قرار كرفته است.

ويزٔكىهاى فيزيكى و شيميايى بسترهاى رشد مورد استفاده تعدادى از ويزز كى هـاى فيزيكسى و شـيميايى بسـترهاى مـورد

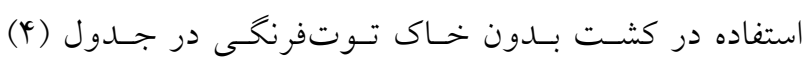
مشاهده مىشود. جّحالى ظـاهرى بسـترهاى رشـــ بـر اسـاس

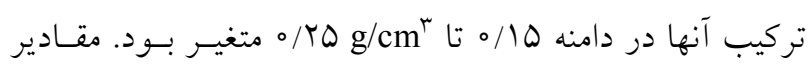

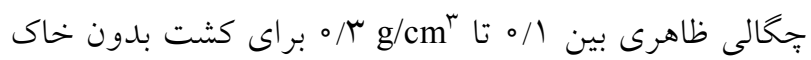




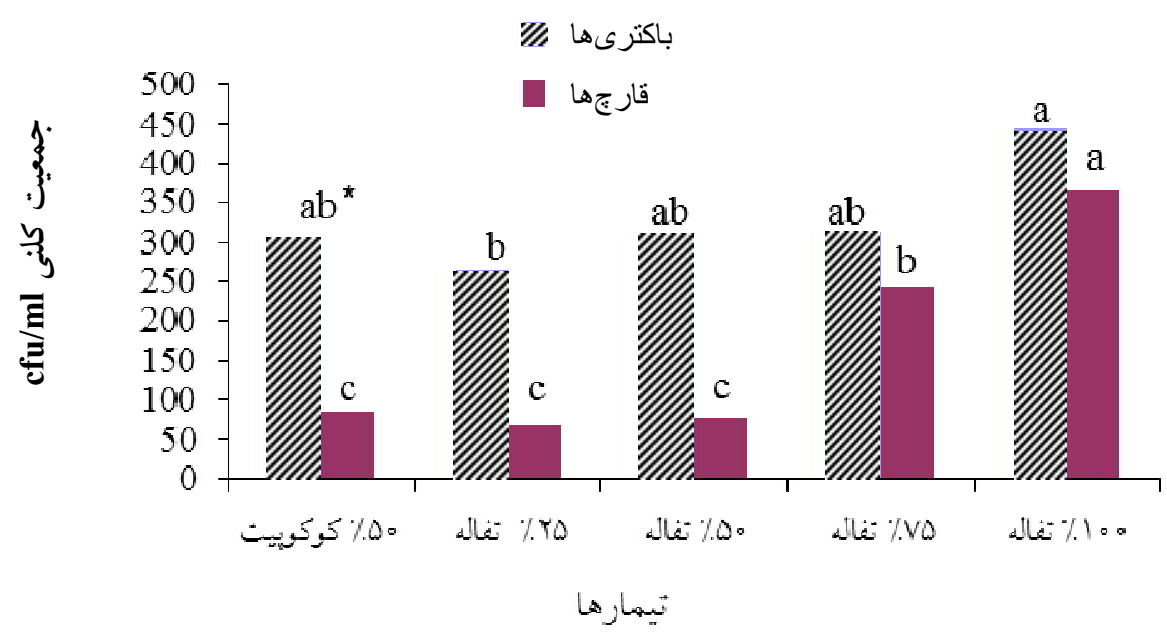

شكل ا. جمعيت كلنى ريزجانداران مختلف حاصل از زهآب بسترهاى رشد توتفرنكى رقم سلوا يٍ از ؟ ماه (هفته آخر) كشت. در هر

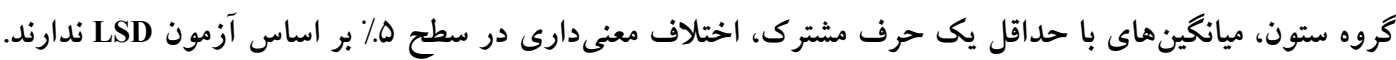

قادرند روى ريشه تشكيل كلنى دهنـــ و ميسـليومهـا در درون بستر رشد كسترش مىيابند. بنابراين، جمعيـت قـارجى ممكـن

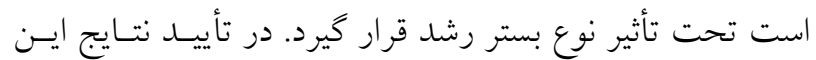

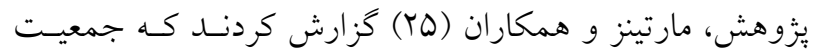

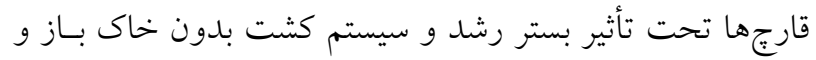

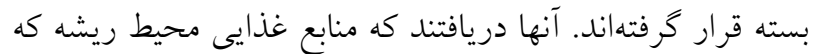
در دسترس ريزجانداران قرار مى گيرد عامل مهمس در جمعيـت فران ميكروبى بستر رشد است (YQ)). نظر به اينكه ريشه شسيرينبيـان

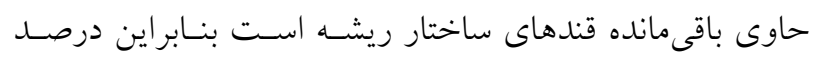

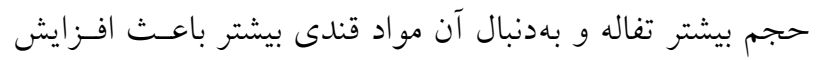

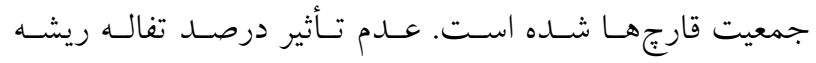
شيرين بيان بر جمعيت باكترىها و يكسانبودن جمعيت آنها در هر

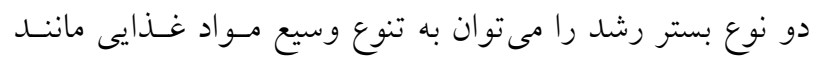

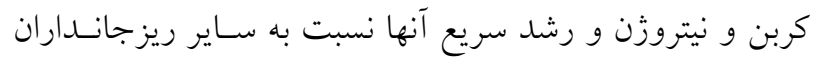

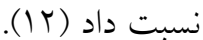

تأثير نوع بستر رشد بر شاخصهاى رشد گياه توتفرنغى

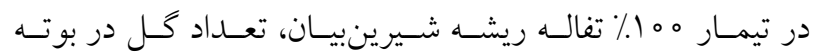
توتفرنخى با اختلاف معنى دار كاهش يافت؛ امـا تعسداد ميـوه در

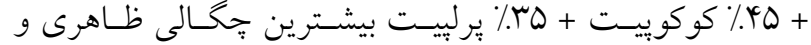
بيشترين كنجايش نخهـدارى آب را نسـبت بـه سـاير بسـترهاى

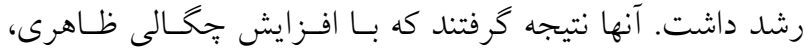

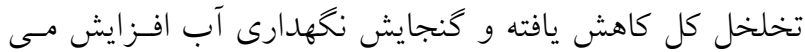

بررسى جمعيت ميكروبى زهآب بسترهاى مختلـف رشــد در

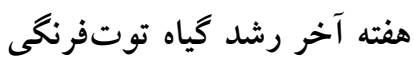
شكل (1)، اثر بسترهاى مختلف رشد بر جمعيـت ريزجانــاران

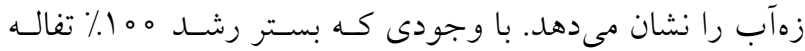
ريشه شيرين بيان بيشترين جمعيـت باكتريـايى را دارا اسـت امـا اختلاف معنىدار بين جمعيت باكتريايى بسترهاى مختلف رشـد

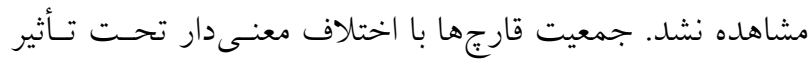

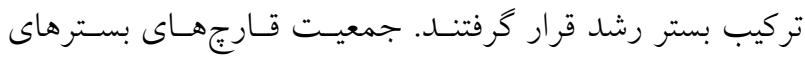
رشد هT و •ه درصد تفاله اختلاف معنى دارى با جمعيت قـارج

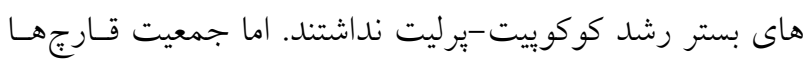

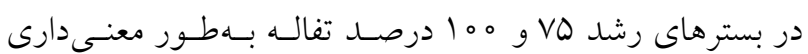

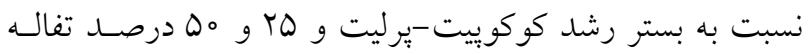
بيشتر بودند. كوهاكان و همكاران (Yo) اظهار داشـتند قـارجهـا 
بسترهاى VD و ه م ا درصد تفاله بهطور معنى دارى نسبت بـه بسـتر كوكوييت -برليت و بسترهاى ها و •ه درصد تفاله بـهترتيـب داراى بيشترين جمعيت كلنى قارجها بودند. بنابراين، ويزگحىهـاى افزايش جمعيت قارجهـا در منطقـه ريشـهـ نيـز ممكـن اسـت بـر عملكـرد فيزيولوزيك معمول كياه تأثير كذاشـته و باعـث كـاهش فتوسـتنز و عملكرد گياهان اين تيمارها شده است. كاهش معنى دار وزن تازه شاخساره، وزن خشك شاخساره و شاخص سبزينگى در تيمارهاى VD و ه ه ا درصد تفالـه نيـز مشاهده شد (جدول ه). كاهش مقادير اين شاخصهـا بيـانخر كاهش فتوسنتز است و نشان مىدهد انتقـال كربوهيـدرات بـهـ ميوهها نيز كاهش يافته است. عموماً يذّيرفته شــده كـه انـدازه

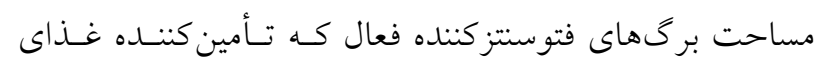
ميوه است فاكتور تعيسين كنتــده بــراى انــدازه ميـوه اسـت (ه). كياهان بستر رشد كوكوييت-يرليت داراى بيشترين عملكـرد و مقدار شاخص سبزينكى بودند. بنابراين، افـزايش انــدازه ميـوه

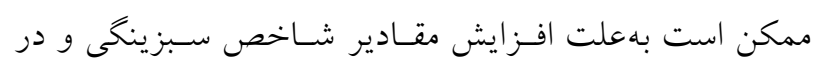
نتيجه افـزايش فعاليـت فتوسـتنزى بـركهـا در گياهـان بسـتر

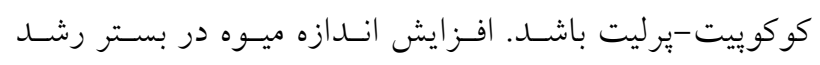
كوكوييت-يرليت نسبت به خاك نيز گزارش شده اسـت (YV). يزّوهشهاى ديلمقانى و همكار ان (9) كه اثر بسترهاى مختلف

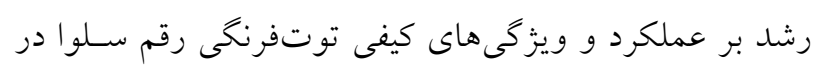

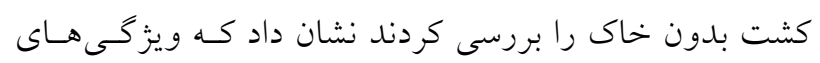
كمّى و كيفى ميوه توت فرنكى در كشت هيدرويونيك به تركيب

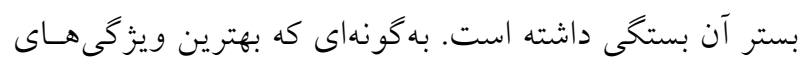

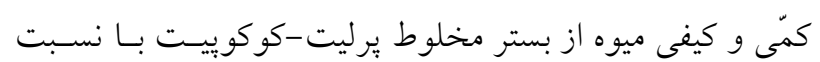

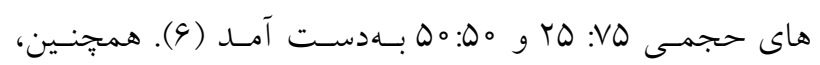

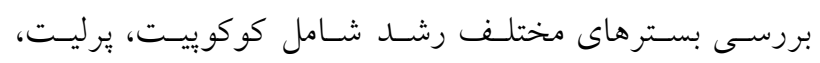

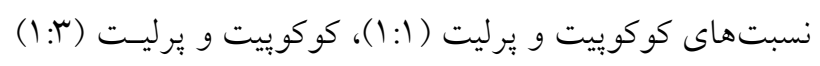

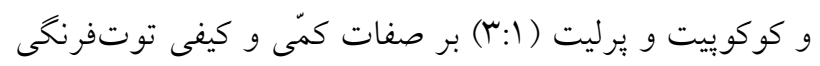

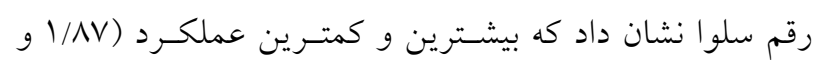

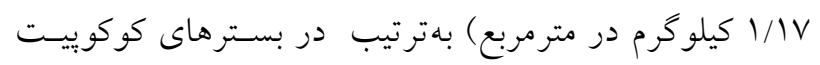

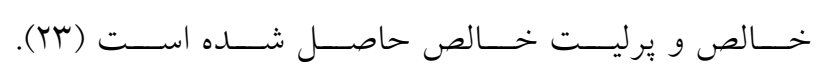

كياه تحت تأثير تيمارها قرار نخرفت. عملكرد بوتهها در هر كلدان تحت تأثير بسترهاى رشد قرار كرفت. به گونسهاى كـه گياهـان در بسترهاى رشد هV و ه ه ا درصد تفاله كمترين عملكــرد را نشـان

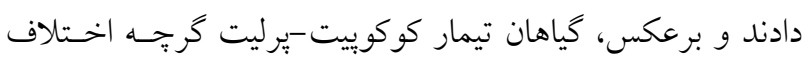

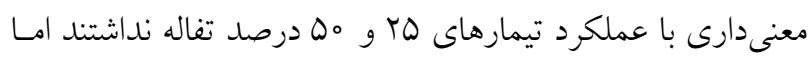
بيشترين عملكرد را نشان دادند (جدول ه). عملكرد يك گياه برآيند دو فاكتور تعداد و انــازه ميـوه بـوده و اين دو نيز نشاندهنده قدرت رشد گياه هستند. نظر به اينكـهـ تعـداد ميوه بين تيمارهاى مختلف تفاوتى نشان نداد، اخـتلاف در عملكـرد

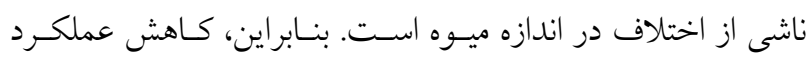

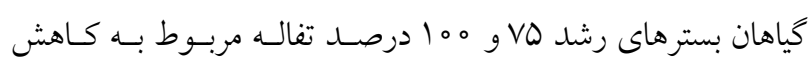

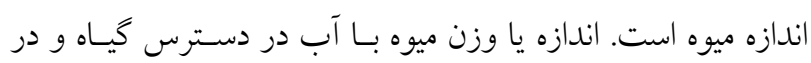
بستر رشد ارتباط مستقيمى دارد. از طرف ديخر، توانايى گيـاه بـراى

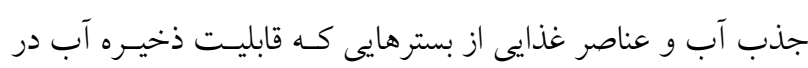
منطقه ريشه و نيز آب قابل دسترس گيـاه را بـا محسـدوديت رويسرو مىسازند بهشدت كاهش مىيابد. بنابراين، بـا كـاهش آب در كيـاه، تعداد برگ، سطح برگ، وزن و اندازه ميوه تحت تأثير قرار مى گيـرد (r). كاهش اندازه ميوه و بهدنبال آن كاهش عملكرد در اين تيمارهـا ممكن است بهعلت شرايط ايجادشده در بستر رشد باشـد كـه مـانع

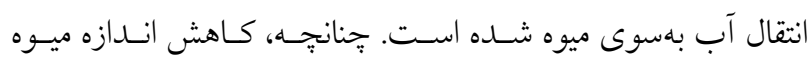
توتفرنكى در شرايط شورى و تغيير تعادل بيتانسيل اسـمزى ريشـهـ نيز مشاهده شده است (19). نظر به اينكه افزايش ميزان درصد تفاله در اين دو بستر رشــ (VD و ه ه ا درصــ تفالـه) نسـبت بـه سـاير بسترهاى رشد باعث افزايش جّخالى ظاهرى و گنجـايش نخهـدارى آب شده است؛ بنابر اين كمبود آب در اطـراف محسيط رشــ ريشـه متتفى است. حدس زده مىشود عواملى مانند ايجاد شرايط مانـدابى و كاهش اكسيزن بستر رشد باعث كاهش فعاليـت متابوليـك ريشـهـ براى جذب آب و عناصر غذايى شده است. تحـت شـرايط كمبـود اكسيزن، انرزى سلولهاى ريشه تا حد زيادى كـاهش مسىيابـد. در نتيجه، جذب فعال و غيرفعال مختل مىشود. افزون بر اين، يكى از ييامدهاى فيزيولوزيك كاهش اكسيززن، بستهدن روزنسهــاى بـرى است كه باعث كاهش تعـرق، فتوسـتز و عملكـرد مسىشـود (1) (1). 


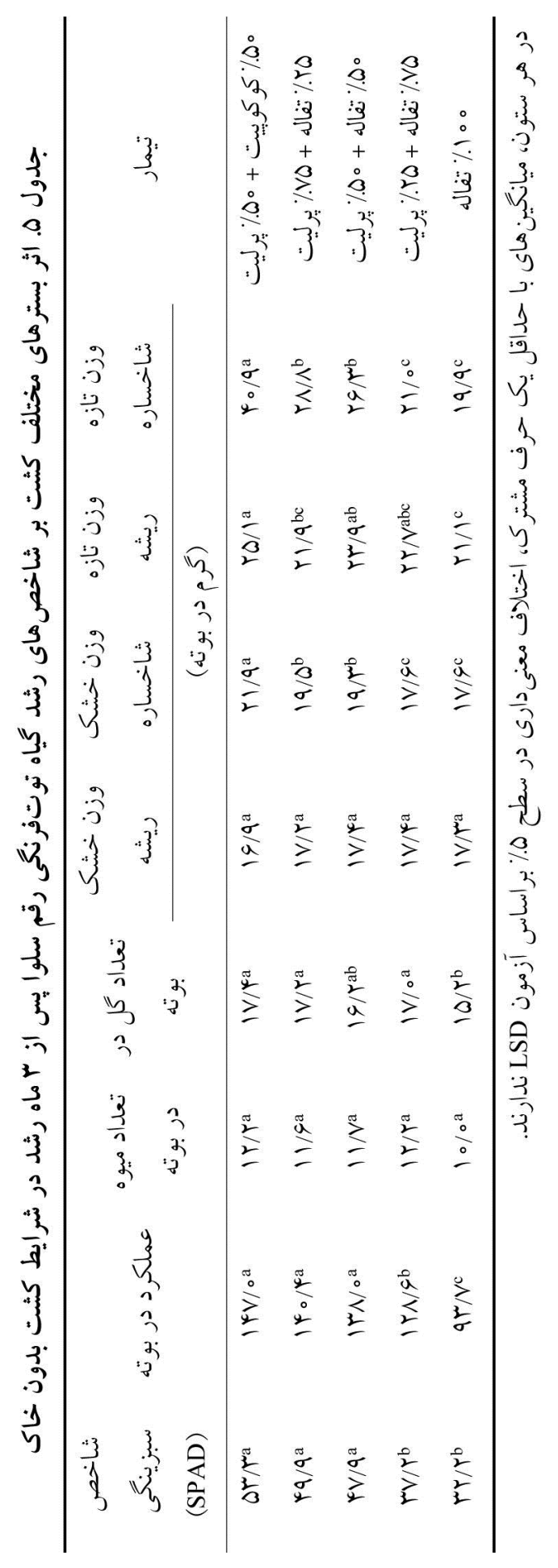


جدول 9. مقايسه ميانگين اثر بسترهاى مختلف رشد بر غلظت عناصر غذايى شاخساره (ميلى گرم بر كيلوگرم ماده خشك) گياه توتفرنخى

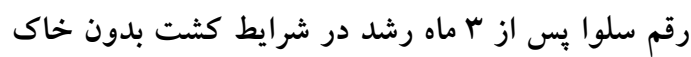

\begin{tabular}{|c|c|c|c|c|c|c|}
\hline $\mathrm{Mn}$ & $\mathrm{Cu}$ & $\mathrm{Zn}$ & $\mathrm{Fe}$ & K & $\mathrm{P}$ & تيمار \\
\hline$r \Delta^{b}$ & $\varphi^{\mathrm{cd}}$ & $\Delta \circ b$ & $V \circ b$ & $r \Delta^{a}$ & rVo。a & •ه.\% كوكوييت + •هـ/ يرليت \\
\hline prab & rbc & $q \mu^{\mathrm{a}}$ & $V q^{b}$ & $r r^{a}$ & $19 \wedge^{b}$ & ه \% \\
\hline$q V^{a b}$ & pa & $\Delta 1^{b}$ & $V Y^{b}$ & rya & raY०b & •هـ\% تفاله + •هـ٪ يرليت \\
\hline crab & $r^{d}$ & $y_{\circ} c$ & $90^{\mathrm{a}}$ & $r r^{\mathrm{a}}$ & $Y Y \circ \Lambda$ & VD\% تفاله + VD ب برليت \\
\hline$q r^{a}$ & $\mu^{b}$ & $r \Delta^{c}$ & $104 a$ & $r I^{a}$ & TYVIC & هـ 1\% تفاله \\
\hline
\end{tabular}

در تفاله ريشه شيرينبيان بـهــورت قابـل تـوجهى بيشـتر از

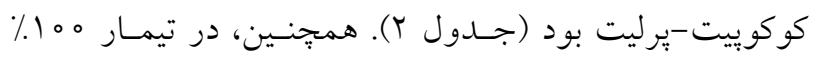
تفاله ريشه شيرينبيان، بهدليل وجود شرايط احيا، غلظت قابـل

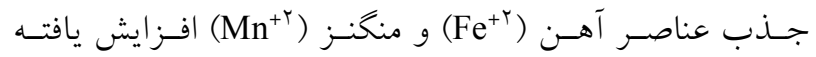
است. كاربرد نسبتهاى مختلف تفاله شيرين بيان سبب كاهش معنى دار غلظت فسفر شاخساره توتفرنكى شـد (جـدول 9).

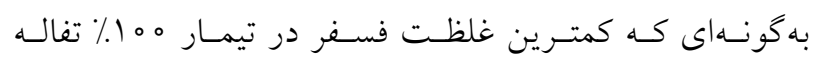

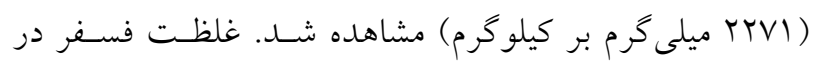
تفالـه ريشـه شـيرينبيـان حسـود دو برابـر غلظـت فسـفر در كوكوبيت است (جدول Y). اما با اين وجــود، در اتــــ افـزايش نسبت تفاله ريشه شيرينبيان به بستر رشـد، غلظـت فسـفر در كياه كاهش يافت. كاهش غلظت فسفر مىتواند بهدليل افزايش بستر رشد و ايجاد شرايط بى هوازى در اثر افزايش نسـبت تفاله ريشه شيرينبيان در بستر رشد و در نتيجه جـذب كمتـر فسفر توسـط ريشـهـ باشـد. غلظـت يتاسـيم شاخسـاره در اثـر افزودن تفاله ريشه شيرينبيان به بستر رشد كاهش يافت؛ ولسى از نظر آمارى اختلاف معنى دارى نداشت (جــدول 9). غلظـت روى( (Zn) شاخساره نيز با كاربرد تيمـار هY\%٪ تفالـه بـهــور معنى دارى افزايش يافـت. ولى كـاربرد تيمارهـاى DV و هـ درصد تفاله سبب كاهش معنىدار غلظت Zn شاخساره شد. به نظر مىرسد كه افزايش pH بستر رشد و ايجـاد شـرايط احيـا سبب كاهش جذب اين عنصر توسط ريشه در تيمارهاى DV و
كوكوييت داراى pH اسيدى، كنجــايش تبـادل كـاتيونى زيـاد، كنجايش نخهدارى آب و درصد تخلخل زيـاد اسـت. بنـابراين، تهويه و زهكشى مناسب، شرايط رشد مناسـبتــرى بـراى گيـاه فراهم مى آورد (YV). كنجايش تبادل كاتيونى زياد در كوكويـت

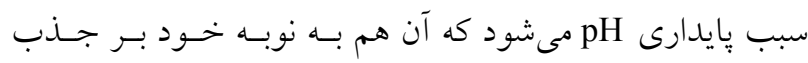
عناصر غذايى تأثير دارد (آ⿱). افزايش عملكرد و مقدار شاخص

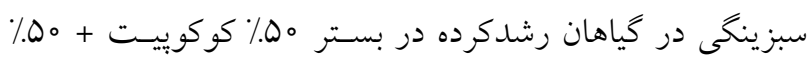
يرليت ممكن است بـهدليـل ويزخى هـاى فيزيكى و شـيميايى مناسب براى رشد توتفرنكى باشـد. از ايسن نظـر كـهـ مقـادير

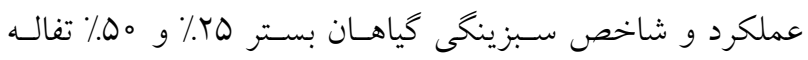
تفاوت معنى دار با مقادير عملكرد و شاخص سـبزينكى گياهـان بستر كوكوييـت هِيرليـت نداشـتند، مسىتـوان اسـتنباط كـرد كـهـ تركيبهاى اين دو بستر نيز شـرايطى مناسـب و مشـابه تركيـب بستر كوكوبيت تيرليت فراهم آوردهاند.

اثر نوع بسـتر رشـــ بــر غلظـت عناصـر غـذايـ شاخسـاره توتفرنكى با افزايش نسبت تفاله ريشه شيرينبيان به كوكوبيـت در بسـتر رشد، غلظت آهن و منخخنز در شاخساره تـوتفرنخـى افـزايش يافت. بهطورى كه تأثير تيمار ه م 1\% تفاله شيرينبيان اخـتلاف معنى دارى با تيمار شاهد (كوكويّت بِيرليـت) داشـت (جــدول 9). اين نتيجه قابل انتظار بود، زيرا غلظت عناصر آهن و منخنز 


\section{نتيجه گيرى}

نتايج واكاوى شيميايى، فيزيكى و ميكرويسى كوكويـت و تفالـه

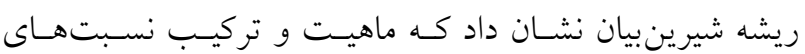

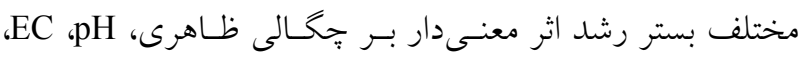
جمعيت كلنى ميكروبى بستر رشد و عملكرد گياه تـوتفرنخى دارد. بستر تفاله در هفته اول كشت، بدون محلول غذايى، داراى عناصر غذايى و pH بيشتر، اما ميـزان EC كمتـــ از بسـتر رشــ كوكوييت-يرليت بود. روند نسبتهاى pH و EC بسترها يس از كاربرد محلول غذايى و تا آخر دوره كشت برقرار بـود. شـرايط فيزيكى و شـيميايى بسـترهاى مختلـف رشــ آثـار معنسى دار و متفاوتى بر ميزان جذب هر يك از عناصر غذايى داشت. افزايش نسبت تركيب تفاله به بيرليـت باعـث افـزايش جخـالى ظـاهرى، كنجايش نخهارى آب و جمعيت كلنسى ميكروبسى بسـتر رشـد شـد؛ و بــرعكس، باعـث كـاهش مقـادير شـاخص سـبزينكى و عملكرد گيـاه تـوتفرنخـى شـــ. مقـادير شـاخص سـبزينخى و

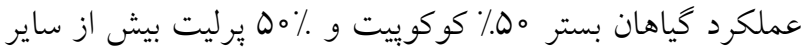

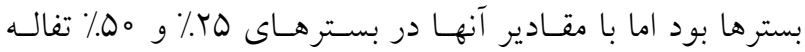
تفاوت آمارى نداشت. با توجه به نتايج، بهنظر مىرسد كه تيمار

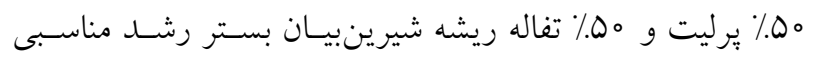
براى جايخزينى بستر رشد حاوى •هـ/ كوكوييت و •هـ/ برليـت
م ا درصد تفاله شده است. تغييرات غلظت مس شاخساره در اثر افزودن نسبتهاى مختلف تفاله ريشه شيرينبيان بـه بسـتر رشد روند منظمى نداشت. در بسيارى از يزوهش هاى انجامشده، رشد كياه تحت تـاثير نوع بستر رشد و تغيير ويزگى هــاى فيزيكى و شـيميايى مانــــ

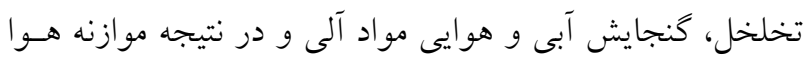
و آب بستر رشد ريشه قرار مى گيرد. با اين وجود، اثـر مثبـت و و منفى يكى گياه و همجنين ريزانداموارهها بر رشد ساير كياهان از طريق آزادسازى تركيبـات شـيمييايى حاصـل از ترشـح ريشـه، شستشو، تبخير و همجنين آزادسازى غيرفعال مواد تجزيهشده به

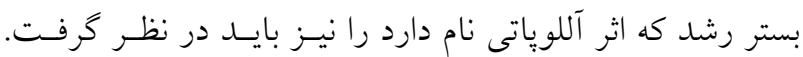
جنانجه در كشت بدون خاك با سير و فلفل، ترشح ريشـه سـير در تراكم بوته كم سير باعث افـزايش ارتفــاع و ميـزان كلروفيـل فلفل شد؛ اما در تراكم بوته زياد سير اثـر معكـوس داشـت (V).

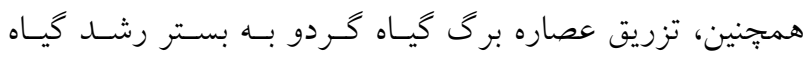
توتفرنخحى كه در شـرايط كشـت بـدون خـاك رشـد مسىكـرد بهشدت مانع رشد رويشى و زايشسى و كـاهش عناصـر غـذايى برگ آن شد (9). بنابراين، احتمال آثار آللوياتى تركيبـات ريشـه شيرينبيان بر رشدونمو كياه توتفرنكى در شرايط اين آزمايش وجود دارد و در : يزوهشهاى آينده قابل بررسى است.

1. Ameri, A., A. Tehranifar, M. Shoor and G.H. Davarynejad. 2012. Effect of substrate and cultivar on growth characteristics of strawberry in soilless culture system. Afr. J. Biotech. 11: 11960-11966.

2. Argo, W.R. and P.R. Fisher. 2008. Understanding Plant Nutrition: Managing Media pH. Greenhouse Grower. http://www.Greenhousgrower.Com/magazine/?Stored=1495.

3. Cantliffe, D., J.N. Shaw, E. Jovicich, J.C. Rodriguez, I. Secker and Z. Karchi. 2001. Passive ventilation high roof greenhouse production of vegetable in a humid mild winter climate. Acta Hort. 559: 515-520.

4. Carlile, W.R., C. Cattivello and P. Zaccheo. 2015. Organic growing media: Constituents and properties. Vadose Zone J. 14: 11539-11663.

5. Caruso, G., G. Villari, G. Melchionna and S. Conti. 2011. Effects of cultural cycles and nutrient solutions on plant growth, yield and fruit quality of alpine strawberry (Fragaria vesca L.) grown in hydroponics. Acta Hort. 129: 479485.

6. Dilmaghani, M.R. and S. Hemmaty. 2011. Effect of different substrates on nutrients content, yield and quality of strawberry cv. Selva in soilless culture. J. Sci. Technol. Greenhouse Culture 7: 1-7. (In Persian)

7. Ding, H., Z. Cheng, M. Liu, S. Hayat and H. Feng. 2016. Garlic exerts allelopathic effects on pepper physiology in a hydroponic co-culture system. Co. Biol. 5: 631-637. 
8. Ebrahimi, R., M.K. Souri, F. Ebrahimi and M. Ahmadizadeh. 2012. Growth and yield of strawberries under different potassium concentrations of hydroponic system in three substrates. World Appl. Sci. J. 16: 1380-1386.

9. Ercisli, S., A. Esken, E. Turkkal and E. Orhan. 2005. The allelopathic effects of Juglone and walnut leaf extracts on yield, growth, chemical and PNE compositions. Plant Soil Environ. 51: 283-287.

10. Fascell, G. and G.V. Zizzo. 2005. Effect of growing media on yield and quality of soilless cultivated rose. Acta Hort. 697: 133-138.

11. Fernandes, C. and J. Edvardo Cora. 2004. Bulk density and relationship air/water of horticultural substrate. Sci. Agric. 61: 446-450.

12. Glick, B.R. 1995. The enhancement of plant growth by free-living bacteria. Can. J. Microbiol. 41: 109-117.

13. Hargreaves, J.C., M.S. Adl, P.R. Warman and H.P.V. Rupasinghe. 2008. The effects of organic and conventional nutrient amendments on strawberry cultivation fruit yield and quality. J. Sci. Food Agric. 88: 2669-2675.

14. Hernanz, D., A.F. Recamales, A.J. Melendez-Martinez, M.L. Gonzalez-Miret and F.J. Heredia. 2008. Multivariate statistical analysis of the color-anthocyanin relationships in different soilless-grown strawberry genotypes. J. Agric. Food Chem. 56: 2735-2741.

15. Herzog, M., G.G. Striker, T.D. Colmer and O. Pederson. 2016. Mechanisms of waterlogging tolerance in wheat - a review of root and shoot physiology. Plant Cell Environ. 39: 1068-1086.

16. Hosseini, S.M.A., M.K. Souri, N. Farhadi, M. Moghadam and R. Omidbeigi. 2014. Changes in glycyrrhizin content of Iranian licorice (Glycyrrhiza glabra L.) affected by different root diameter and ecological conditions. Agric. Commun. 2: 27-33.

17. Kalra, Y.P. 1998. Handbook of Reference Methods for Plant Analysis. CRC Press.

18. Kampf, A.N., P.A. Hammer and T. Kirk. 1999. Effect of packing density on the mechanical impedance of root media. Acta Hort. 481: 682-691.

19. Keutgen, A.J. and E. Pawelzik. 2008. Quality and nutritional value of strawberry fruit under long term salt stress. Food Chem. 55: 1612-1619.

20. Koohakan, P., H. Ikeda, T. Jeanaksorn, M. Tojo, S.I. Kussakari, K. Okada and S. Sato. 2004. Evaluation of the indigenous microorganisms in soilless culture: Occurrence and quantitative characteristics in the different growing systems. Sci. Hort. 101: 179-188.

21. Kuisma, E., P. Palonen and M. Yli-Halla. 2014. Reed Canary grass straw as substrate in soilless cultivation of strawberry. Sci. Hort. 178: 217-223.

22. Mardanluo, S., M.K. Souri and M. Ahmadi. 2018. Plant growth and fruit quality of two pepper cultivars under different potassium levels of nutrient solutions. J. Plant Nutr. 41: 1604-1614.

23. Mashhadi Jafarlou, A., M. Henareh and A. Samadi. 2016. Effect of plant density and culture medium on quantitative and qualitative characteristics of strawberry cv. Selva in hydroponic cultivation. Pomology Res. 1: 30-42. (In Persian)

24. Martinez, F., J. Alberto Oliveira, E. Oliveira Calvete and P. Palencia. 2017. Influence of growth medium on yield, quality indexes and SPAD values in strawberry plant. Sci. Hort. 217: 17-29.

25. Martinez, F., S. Castillo, C. Borrero, S. Péres, P. Palencia and M. Avilés. 2013. Effect of soilless growing systems on the biological properties of growth media in strawberry. Sci. Hort. 150: 59-64.

26. Medina, S., A. Krassnovsky, A. Yogev and M. Raviv. 2011. Horticultural characteristics of Licorice waste compost. Compost Sci. Util. 19: 163-169.

27. Noguera, P., M. Abad, V. Noguera, R. Puchades and E. Maquieira. 2000. Coconut coir waste, a new and ecologically-friendly peat substrate. Acta Hort. 517: 279-286.

28. Pourranjbari Saghaiesh, S., M.K. Souri and M. Moghaddam. 2019. Characterization of nutrients uptake and enzymes activity in Khatouni melon (Cucumis melo var. Inodorus) seedlings under different concentrations of nitrogen, potassium and phosphorus of nutrient solution. J. Plant Nutr. 42: 1-8.

29. Rajaie, M., M. Attarzadeh, S.H. Mosavi and M. Attarzadeh. 2015. Using licorice compost (Glycyrrhiza glabra) to reduce the water stress effect in greenhouse cucumber. J. Agric. Sci. Sustain. Prod. 3: 79-90. (In Persian)

30. Shinohara, Y., T. Hata, T. Maruo, M. Hohjo and T. Ito. 1999. Chemical and physical properties of the coconut-fiber substrate and the growth and productivity of tomato (Lycopersicom esculentum Mill.) plants. Acta Hort. 481: 145149.

31. Sonnereld, C. and W. Voogt. 2009. Plant Nutrition of Greenhouse Crops. $1^{\text {st }}$ Ed., Springer.

32. Statistical Center of Iran. 2015. Basic Classification of Iranian Crops based on CPC. Rev. 2, Publications of Statistical Center of Iran. (In Persian)

33. Tohidloo, G., M.K. Souri and S. Eskandarpour. 2018. Growth and fruit biochemical characteristics of three strawberry genotypes under different potassium concentrations of nutrient solution. Open Agric. 3: 356-362.

34. Van Patten, G.F. 2011. Gardening Indoors with Soil and Hydroponics. SI, Patten Pub., pp. 57-110. 


\title{
Feasibility of using Licorice (Glycyrrhiza glabra L.) Root Residue as Growth Medium and Its Effect on Growth Indices and Nutrients Uptake in Soilless Culture of Strawberry
}

\author{
M. R. Safizadeh ${ }^{1^{*}}$, H. R. Boostani ${ }^{2}$ and A. Mirsoleimani ${ }^{1}$
}

(Received: 21 April 2019; Accepted: 30 November 2019)

\begin{abstract}
Licorice root pulp is an organic waste which may be used as a growth medium in soilless culture. A research was conducted in a completely randomized design with 8 replications to assess the efficiency of licorice root pulp as a growth medium for strawberry plant (Selva cv.) under greenhouse conditions for three months. In this experiment, four ratios (v/v) of perlite:licorice root pulp (75:25, 50:50, 25:75 and 0:100\%) were compared with cocopeat:perlite (50:50) as control. Plant growth indices and fungal population of growth medium were significantly affected by the type of medium. Fruit yield and greenness index (SPAD) values were enhanced by the cocopeat-perlite mixture; but there were not significant differences with media comprising of 25 and 50 percent of pulp residue. Bulk density, water holding capacity and fungal population in the media containing 75 and 100 percent of licorice root pulp were higher than other culture media. In addition, plants grown on 75 and 100 percent of licorice root pulp had the lowest yield and SPAD values compared to other treatments. Licorice root pulp had higher contents of nutrients such as $\mathrm{Mn}, \mathrm{Cu}, \mathrm{P}, \mathrm{Fe}$ and $\mathrm{Zn}$, but, its $\mathrm{K}$ and $\mathrm{Na}$ concentrations were less than those in the cocopeat-perlite. Concentrations of Fe and $\mathrm{Mn}$ in the leaves were increased, while concentrations of $\mathrm{P}$ and $\mathrm{Zn}$ were decreased, by increasing the ratio of licorice root pulp in the culture medium.
\end{abstract}

Keywords: Fungal population, Yield, Cocopeat, Greenness index (SPAD).

1. Dept. of Plant Prod., College of Agric. and Nat. Resour. of Darab, Shiraz Univ., Darab, Iran.

2. Dept. of Range and Watershed Manage., College of Agric. and Nat. Resour. of Darab, Shiraz Univ., Darb, Iran.

* Corresponding Author, Email: Safizade@shirazu.ac.ir 